\title{
Syntheses and Crystal Structures of Salts of Hexabromotetraselenate(I) and Hexabromoselenate(IV)bis\{dibromodiselenate(I)\}
}

\author{
Sverre Hauge, ${ }^{a, *}$ Vitalijus Janickis ${ }^{b}$ and Kjartan Marø ${ }^{a, *}$ \\ a Department of Chemistry, University of Bergen, N-5007 Bergen, Norway and ${ }^{b}$ Kaunas University of Technology, \\ Kaunas, Lithuania
}

\begin{abstract}
Hauge, S., Janickis, V. and Marøy, K., 1998. Syntheses and Crystal Structures of Salts of Hexabromotetraselenate(I) and Hexabromoselenate(IV)bis $\{$ dibromodiselenate(I)\}. Acta Chem. Scand. 52: 1104 1109. (C) Acta Chemica Scandinavica 1998.

The title compounds have been prepared from clemental selenium and bromine, and phenyltrimethylammonium bromide or benzyltrimethylammonium bromide. The crystal structures of $\left[\mathrm{C}_{6} \mathrm{H}_{5}\left(\mathrm{CH}_{3}\right)_{3} \mathrm{~N}_{2}\left[\mathrm{Se}_{4} \mathrm{Br}_{6}\right]\right.$ (1), $\left[\mathrm{C}_{6} \mathrm{H}_{5} \mathrm{CH}_{2}\left(\mathrm{CH}_{3}\right)_{3} \mathrm{~N}\right]_{2}\left[\mathrm{Se}_{4} \mathrm{Br}_{6}\right]$ (2) and $\left[\mathrm{C}_{6} \mathrm{H}_{5}\left(\mathrm{CH}_{3}\right)_{3} \mathrm{~N}\right]_{2}\left[\mathrm{SeBr}_{6}\left(\mathrm{Se}_{2} \mathrm{Br}_{2}\right)_{2}\right]$ (3) were determined by X-ray methods. Crystals of 1 and 2 are monoclinic. space group $P 2_{1} / c$ (No. 14) with $Z=2$ and $a=8.618(2), b=12.914(2), c=13.609(3) \AA$ and $\beta=95.13(2)^{\circ}$ for 1 , and $a=8.417(2), b=12.673(3), c=14.813(3) \AA$ and $\beta=$ for $97.06(3)^{\circ}$ for 2 . The crystals of $\mathbf{3}$ are monoclinic, space group $P 2 / n$ (No. 14) with $Z=2$ and $a=8.683(2), b=12.762(3), c=16.340(3) \AA, \beta=$ $104.29(3)^{\circ}$. The anions of 1 and 2 consist of two $\mathrm{Br}-\mathrm{Se}-\mathrm{Se}-\mathrm{Br}$ units bonded together by two $\mathrm{Br}$ atom bridges between the $\mathrm{Se}$ atoms in such a way that a chair-shaped, six-membered ring is formed and the $\mathrm{Se}-\mathrm{Br}$ bonds of the $\mathrm{Br}-\mathrm{Se}-\mathrm{Se}-\mathrm{Br}$ units are pointing out of the ring. The anion of 3 is a nearly regular $\mathrm{SeBr}_{6}$ octahedron where two trans-positioned $\mathrm{Br}$ atoms each have a weak bond to one of the $\mathrm{Se}$ atoms in $\mathrm{Se}_{2} \mathrm{Br}_{2}$ molecule.
\end{abstract}

Selenium and bromine form the binary compounds $\mathrm{Se}_{2} \mathrm{Br}_{2}, \mathrm{SeBr}_{2}$ and $\mathrm{SeBr}_{4}$. In addition $\mathrm{Se}_{3} \mathrm{Br}_{2}$ and $\mathrm{Se}_{4} \mathrm{Br}_{2}$ are formed by disproportion of $\mathrm{Se}_{2} \mathrm{Br}_{2}$. Crystal structures of $\mathrm{Se}_{2} \mathrm{Br}_{2}$ and $\mathrm{SeBr}_{4}$ are well known; ${ }^{1,2}$ both compounds exist in allotrope modifications. $\mathrm{SeBr}_{2}$ has not been isolated. Both $\mathrm{SeBr}_{2}$ and $\mathrm{SeBr}_{4}$ make series of complexes with bromide; with divalent selenium the anions $\mathrm{SeBr}_{4}{ }^{2-},{ }^{3,4} \mathrm{Se}_{2} \mathrm{Br}_{6}{ }^{2-},{ }^{3,5} \mathrm{Se}_{4} \mathrm{Br}_{14}{ }^{2-, 6,7} \mathrm{Se}_{3} \mathrm{Br}_{8}{ }^{2-,},{ }^{7-9}$ and $\mathrm{Se}_{5} \mathrm{Br}_{12}{ }^{2-},{ }^{7}$ and with tetravalent selenium the anions $\mathrm{SeBr}_{6}{ }^{2-}, 8,10,11 \quad \mathrm{Se}_{2} \mathrm{Br}_{9}{ }^{-8,12} \quad \mathrm{Se}_{2} \mathrm{Br}_{10}{ }^{2-},{ }^{11-13}$ and $\mathrm{Se}_{3} \mathrm{Br}_{13}-14$

Selenium reacts with bromine in acetonitrile, and when the $\mathrm{Se} / \mathrm{Br}_{2}$ ratio is 2.0 the product is mainly $\mathrm{Se}_{2} \mathrm{Br}_{2}$ :

$2 \mathrm{Se}+\mathrm{Br}_{2} \rightleftharpoons \mathrm{Se}_{2} \mathrm{Br}_{2}$

However, the reaction is not quantitative, since both $\mathrm{Se}_{2} \mathrm{Br}_{2}$ and $\mathrm{Br}_{2}$ are parts of the equilibrium:

$2 \mathrm{SeBr}_{2} \rightleftharpoons \mathrm{Se}_{2} \mathrm{Br}_{2}+\mathrm{Br}_{2}$

The $K$ value for the last reaction in acetonitrile is 0.014-0.14. ${ }^{15,16}$ Other compounds, such as $\mathrm{SeBr}_{4}, \mathrm{Se}_{3} \mathrm{Br}_{2}$ and $\mathrm{Se}_{4} \mathrm{Br}_{2}$, will also be minor parts in the equilibrium. By adding bromide to the solution, the possibility of

\footnotetext{
* To whom correspondence should be addressed.
}

obtaining a complex with monovalent selenium should be good, but which species will crystallise from the solution depends on the concentration equilibrium and solubilities. This work reports the first complexes of univalent selenium.

\section{Experimental}

Preparations. The present compounds are among a series prepared by reactions between elemental selenium and bromine in the presence of complex cations. ${ }^{4,5}$

Preliminary reactions were done to find out how the presence of bromide will influence the oxidation state of $\mathrm{Se}$ in a selenium-bromine mixture.

To $4 \mathrm{mmol}(0.639 \mathrm{~g}) \mathrm{Br}_{2}$ in $20 \mathrm{~g}$ of acetonitrile were added $8 \mathrm{mmol}(0.632 \mathrm{~g})$ of selenium. The mixture was stirred at room temperature for $1 \mathrm{~h}$ and $0.036 \mathrm{~g}(6 \%)$ of undissolved selenium was isolated.

To the same amount of selenium, bromine and acetonitrile as above were added $4 \mathrm{mmol}(0.865 \mathrm{~g})$ of $\left[\mathrm{C}_{6} \mathrm{H}_{5}\left(\mathrm{CH}_{3}\right)_{3} \mathrm{~N}\right] \mathrm{Br}$. The mixture was treated as above, and $0.230 \mathrm{~g}(28 \%)$ undissolved selenium was isolated.

Determination of selenium was done by treating the sample with a sulfite solution, adding bromide and oxidising with bromine. Excess bromine was removed, 
and the amount of selenium was determined iodometrically. Bromide was determined by potentiometric titration with silver nitrate. Densities were measured by the method of flotation, using a mixture of trichloromethane and tribromomethane.

$\left[\mathrm{C}_{6} \mathrm{H}_{5}\left(\mathrm{CH}_{3}\right)_{3}\right]_{2}\left[\mathrm{Se}_{4} \mathrm{Br}_{6}\right]$ (1). To $6.0 \mathrm{mmol}(0.474 \mathrm{~g})$ of selenium and $3.0 \mathrm{mmol}(0.648 \mathrm{~g})$ of phenyltrimethylammonium bromide in $8.0 \mathrm{~g}$ of acetonitrile were added $4.5 \mathrm{mmol}(0.72 \mathrm{~g})$ bromine. After being stirred and heated to $40^{\circ} \mathrm{C}$, the solution was clear, dark brown. After being set aside for $3 \mathrm{~h}$ in a refrigerator, $1.0 \mathrm{~g}$ of dark red crystals of $\left[\mathrm{C}_{6} \mathrm{H}_{5}\left(\mathrm{CH}_{3}\right)_{3} \mathrm{~N}\right]_{2}\left[\mathrm{SeBr}_{6} \cdot\left(\mathrm{Se}_{2} \mathrm{Br}_{2}\right)_{2}\right]$ was isolated. The filtrate was placed overnight in a freezer at $-22^{\circ} \mathrm{C}$. Next day $0.49 \mathrm{~g}$ of a mixture of dark red and bright red crystals was isolated. The dark red crystals were $\left[\mathrm{C}_{6} \mathrm{H}_{5}\left(\mathrm{CH}_{3}\right)_{3} \mathrm{~N}\right]_{2}\left[\mathrm{SeBr}_{6} \cdot\left(\mathrm{Se}_{2} \mathrm{Br}_{2}\right)_{2}\right]$ and the bright red crystals were $\left[\mathrm{C}_{6} \mathrm{H}_{5}\left(\mathrm{CH}_{3}\right)_{3} \mathrm{~N}\right]_{2}\left[\mathrm{Se}_{4} \mathrm{Br}_{6}\right]$. It was easy to separate the bright red crystals. Found: $\mathrm{Se}$ 28.55, Br 44.80. Calc. for $\left[\mathrm{C}_{6} \mathrm{H}_{5}\left(\mathrm{CH}_{3}\right)_{3} \mathrm{~N}\right]_{2}\left[\mathrm{Se}_{4} \mathrm{Br}_{6}\right]$ : Se 29.58, Br 44.90 .

$\left[\mathrm{C}_{6} \mathrm{H}_{5} \mathrm{CH}_{2}\left(\mathrm{CH}_{3}\right)_{3} \mathrm{~N}_{2}\left[\mathrm{Se}_{4} \mathrm{Br}_{6}\right] \quad\right.$ (2). To $6.0 \mathrm{mmol}$ $(0.474 \mathrm{~g})$ of selenium in $4.0 \mathrm{~g}$ of acetonitrile were added $3.0 \mathrm{mmol}(0.479 \mathrm{~g})$ of bromine. The mixture was stirred and heated to $60^{\circ} \mathrm{C}$. Small amounts of selenium did not react. $3 \mathrm{mmol}(0.691 \mathrm{~g})$ of benzyltrimethylammonium bromide were added to the mixture, and the temperature was raised to $75^{\circ} \mathrm{C}$. Some selenium was filtered off. After being left at room temperature for $2 \mathrm{~h}, 0.55 \mathrm{~g}$ of thin brown plates were isolated. The filtrate was placed in refrigerator for $6 \mathrm{~h}$, and $0.31 \mathrm{~g}$ more of the compound was isolated. Found: $\mathrm{Se} 28.52, \mathrm{Br}$ 43.30. Calc. for $\left[\mathrm{C}_{6} \mathrm{H}_{5} \mathrm{CH}_{2}\left(\mathrm{CH}_{3}\right)_{3}\right]_{2}\left[\mathrm{Se}_{4} \mathrm{Br}_{6}\right]$ : Se 28.82, $\mathrm{Br} 43.75$.

$\left[\mathrm{C}_{6} \mathrm{H}_{5}\left(\mathrm{CH}_{3}\right)_{3} \mathrm{~N}_{2}\left[\mathrm{SeBr}_{6} \cdot\left(\mathrm{Se}_{2} \mathrm{Br}_{2}\right)_{2}\right]\right.$ (3). To $6.0 \mathrm{mmol}$ $(0.474 \mathrm{~g})$ of selenium and $2.4 \mathrm{mmol}(5.19 \mathrm{~g})$ of phenyltrimethylammonium bromide in $8 \mathrm{~g}$ of acetonitrile were added $4.8 \mathrm{mmol}(0.767 \mathrm{~g})$ of bromine. The mixture was stirred and heated until the solution was clear with a dark brown colour. After $2 \mathrm{~h}$ at room temperature $0.14 \mathrm{mmol}(0.12 \mathrm{~g})$ of phenyltrimethylammonium hexabromoselenate(IV), $\left[\mathrm{C}_{6} \mathrm{H}_{5}\left(\mathrm{CH}_{3}\right)_{3} \mathrm{~N}\right]_{2}\left[\mathrm{SeBr}_{6}\right]$, was isolated. The filtrate was again left at room temperature for $2 \mathrm{~h}$, and $0.58 \mathrm{mmol}(0.85 \mathrm{~g})$ of dark red prisms was isolated. Found: $\mathrm{Se} 26,57, \mathrm{Br} 53.80$. Calc. for $\left[\mathrm{C}_{6} \mathrm{H}_{5}\left(\mathrm{CH}_{3}\right)_{3} \mathrm{~N}\right]_{2}\left[\mathrm{SeBr}_{6}\left(\mathrm{Se}_{2} \mathrm{Br}_{2}\right)_{2}\right]$ : Se 26.93, Br 54.49.

$X$-Ray structure analyses. The determination of unit-cell dimensions and data collections were carried out on an Enraf-Nonius CAD4 diffractometer. Data reductions were performed by XCAD4; ${ }^{17}$ the structures were solved by direct methods using SHELXS $86^{18}$ and refined by SHELXL93. ${ }^{19}$ The crystal data, conditions for data collection, and refinements are summarised in Table 1. Atomic scattering factors were taken from Tables 4.2.6.8 and 6.1.1.4 in Ref. 20.

The numerical absorption corrections in all cases led to reduced $R$ - and $\Delta(\rho)$-values, but for compounds 2 and 3 the values are still larger than expected. The reason may be inaccurate indexing or measurements of the dimensions, since the specimens used were cut from larger crystals.

The data for compound 1 were first collected at $263 \mathrm{~K}$ and refined smoothly to $R=0.042$ for $I>2 \sigma(I)$, but the displacement parameters were generally extremely high and especially for the methyl carbon atoms. A new set of data were then collected at $112 \mathrm{~K}$, but the displacement parameters were still very high for most atoms. We then prepared the benzyltrimethylammonium salt, and the data collected at $114 \mathrm{~K}$ for this compound resulted in normal displacement parameters for all atoms.

The hydrogen atoms were in all structures placed geometrically and refined using a riding model with isotropic thermal parameters equal to $1.3 U(\mathrm{eq})$ for the atom to which they are attached. All non-hydrogen atoms were refined anisotropically.

Final atomic coordinates and equivalent isotropic displacement parameters are listed in Tables 2 and 3 . Complete lists of coordinates, bond lengths and angles, and anisotropic displacement parameters are available from the authors.

\section{Results and discussion}

It was mentioned in the introduction that selenium and bromine form many binary compounds, and addition of bromide as reactant increases the number of variants. The complex anions also set up many equilibria by disproportion and association. From the preliminary experiment where selenium is mixed with bromine in acetonitrile in the molar ratio $2: 1$, a small amount of selenium was undissolved, showing that a little of the selenium is present in a higher oxidation state than +1 . When bromide is present in the reaction mixture much more selenium is undissolved, showing that a larger part of the dissolved selenium has reacted to a higher oxidation state. In complexes the bromine/selenium ratio generally increases with growing oxidation state. It is therefore necessary to keep the concentration of bromide low if complexes of univalent selenium are wanted. In the present synthesis of $\left[\mathrm{C}_{6} \mathrm{H}_{5}\left(\mathrm{CH}_{3}\right)_{3} \mathrm{~N}\right]_{2}\left[\mathrm{SeBr}_{6}\right.$ $\left(\mathrm{Se}_{2} \mathrm{Br}_{2}\right)_{2}$ ], $6 \mathrm{mmol}$ of selenium is mixed with $2.4 \mathrm{mmol}$ of bromide and $4.8 \mathrm{mmol}$ of bromine. If all the bromine reacts with selenium, the average oxidation state of selenium is +1.6 , in accordance with the chemical formula. However, the first compound that crystallizes is $\left[\mathrm{C}_{6} \mathrm{H}_{5}\left(\mathrm{CH}_{3}\right)_{3} \mathrm{~N}\right]_{2}\left[\mathrm{SeBr}_{6}\right]$, showing an equilibrium in the solution involving anions with selenium at +4 and with selenium at lower oxidation states than +1.6 . In the synthesis of $\left[\mathrm{C}_{6} \mathrm{H}_{5}\left(\mathrm{CH}_{3}\right)_{3} \mathrm{~N}\right]_{2}\left[\mathrm{Se}_{4} \mathrm{Br}_{6}\right]$ the average oxidation state of selenium is +1.5 and the bromide concentration is $25 \%$ higher. The effect of lowering of the average oxidation state from 1.6 to 1.5 seems to be enough to prevent the crystallization of the $\mathrm{SeBr}_{6}{ }^{2-}$ ion, in spite of the increase in the bromide concentration. 
HAUGE ET AL.

Table 1. Crystal data and structure refinement.

\begin{tabular}{|c|c|c|c|}
\hline Identification code & 1 & 2 & 3 \\
\hline Empirical formula & $\mathrm{C}_{18} \mathrm{H}_{28} \mathrm{Br}_{6} \mathrm{~N}_{2} \mathrm{Se}_{4}$ & $\mathrm{C}_{20} \mathrm{H}_{32} \mathrm{Br}_{6} \mathrm{~N}_{2} \mathrm{Se}_{4}$ & $\mathrm{C}_{18} \mathrm{H}_{28} \mathrm{Br}_{10} \mathrm{~N}_{2} \mathrm{Se}_{5}$ \\
\hline Temperature/K & $112(2)$ & $114(2)$ & $109(2)$ \\
\hline Wavelength/A & 0.71069 & 0.71069 & 0.71069 \\
\hline Crystal system & Monoclinic & Monoclinic & Monoclinic \\
\hline Space group & $P 2_{1} / c$ & $P 2_{1} / c$ & $P 2_{1} / n$ \\
\hline$a / \AA$ & $8.618(2)$ & $8.417(2)$ & $8.683(2)$ \\
\hline$b / \AA$ & $12.914(2)$ & $12.673(3)$ & $12.762(3)$ \\
\hline$c / \AA$ & $13.609(3)$ & $14.813(3)$ & $16.340(3)$ \\
\hline$\beta /$ & $95.13(2)$ & $97.06(3)$ & $104.29(3)$ \\
\hline Volume $/ \AA^{3}$ & $1508.5(5)$ & $1568(5)$ & $1754.7(6)$ \\
\hline$Z$ & 2 & 2 & 2 \\
\hline$D_{\mathrm{c}} / \mathrm{g} \mathrm{cm}^{-3}$ & 2.35 & 2.32 & 2.78 \\
\hline$D_{\mathrm{o}} / \mathrm{g} \mathrm{cm}^{-3}(293 \mathrm{~K})$ & 2.31 & 2.26 & 2.58 \\
\hline$F(000)$ & 992 & 1024 & 1340 \\
\hline Crystal size/mm & $0.15 \times 0.27 \times 0.31$ & $0.09 \times 0.12 \times 0.40$ & $0.10 \times 0.17 \times 0.27$ \\
\hline$\theta$ range/" & $2.4-26.3$ & $2.9-29.9$ & $2.4-28.0$ \\
\hline \multirow[t]{3}{*}{$h k /$ limits } & $h=-10 \rightarrow 10$ & $h=0 \rightarrow 11$ & $h=0 \rightarrow 11$ \\
\hline & $k=0 \rightarrow 16$ & $k=0 \rightarrow 17$ & $k=0 \rightarrow 16$ \\
\hline & $I=0 \rightarrow 16$ & $I=-20 \rightarrow 20$ & $I=-21 \rightarrow 20$ \\
\hline Intensity decay (\%) & 18.6 & 8.7 & 8.0 \\
\hline Absorption coeff. $/ \mathrm{mm}^{-1}$ & 12.93 & 12.41 & 16.62 \\
\hline Correction for absorption & Numerical & Numerical & Numerical \\
\hline$T_{\min } / T_{\max }$ & $0.043 / 0.180$ & $0.238 / 0.356$ & $0.064 / 0.231$ \\
\hline Independent reflections & 3056 & 4538 & 4235 \\
\hline No. with $I>2 \sigma(/)$ & 2109 & 3507 & 2673 \\
\hline Data/parameters & $2934 / 137$ & $4538 / 148$ & $4233 / 164$ \\
\hline Weight, $P=\left(F_{\mathrm{o}}{ }^{2}+2 F_{\mathrm{c}}{ }^{2}\right) / 3$ & {$\left[\sigma^{2}\left(F^{2}\right)+(0.075 P)^{2}+33.24 P\right]^{-1}$} & {$\left[\sigma^{2}\left(F^{2}\right)+(0.022 P)^{2}+0.91 P\right]^{-1}$} & {$\left[\sigma^{2}\left(F^{2}\right)+(0.102 P)^{2}+51.44 P\right]^{-1}$} \\
\hline Extinction coefficient & $0.0031(5)$ & & $0.0008(3)$ \\
\hline Refinement on & $F^{2}$ & $F^{2}$ & $F^{2}$ \\
\hline Goodness-of-fit on $F^{2}$ & 1.043 & 1.048 & 1.099 \\
\hline$R(F)[I>2 \sigma(I)]$ & 0.0559 & 0.0858 & 0.0537 \\
\hline$R(F)$ (all data) & 0.0996 & 0.1152 & 0.1127 \\
\hline$W R\left(F^{2}\right)[I>2 \sigma(I)]$ & 0.1440 & 0.2419 & 0.1598 \\
\hline$W R\left(F^{2}\right)$ (all data) & 0.1726 & 0.2779 & 0.2031 \\
\hline Max. and $\min . \Delta \rho / e \AA^{-3}$ & 1.27 and -2.07 & 4.32 (near $\mathrm{Se}$ ) and -4.69 & 4.91 (near $\mathrm{Se}$ ) and -3.96 \\
\hline
\end{tabular}

Table 2. Atomic coordinates $\left(\times 10^{4}\right)$ and equivalent isotropic displacement parameters $\left(\right.$ in $\left.\AA^{2} \times 10^{3}\right)$ for 1 and 2 .

\begin{tabular}{|c|c|c|c|c|c|c|c|c|}
\hline \multirow[b]{2}{*}{ Atom } & \multicolumn{4}{|c|}{$\left[\mathrm{C}_{6} \mathrm{H}_{5}\left(\mathrm{CH}_{3}\right)_{3} \mathrm{~N}\right]_{2}\left[\mathrm{Se}_{4} \mathrm{Br}_{6}\right](1)$} & \multicolumn{4}{|c|}{$\left[\mathrm{C}_{6} \mathrm{H}_{5} \mathrm{CH}_{2}\left(\mathrm{CH}_{3}\right)_{3} \mathrm{~N}_{2}\left[\mathrm{Se}_{4} \mathrm{Br}_{6}\right](2)\right.$} \\
\hline & $x$ & $y$ & $z$ & $U(\mathrm{eq})^{a}$ & $x$ & $y$ & $z$ & $U(\mathrm{eq})^{a}$ \\
\hline $\mathrm{Se}(1)$ & $780(2)$ & $1623(1)$ & $5644(1)$ & $34(1)$ & $624(1)$ & $1599(1)$ & $5549(1)$ & $14(1)$ \\
\hline $\mathrm{Se}(2)$ & $2624(1)$ & $377(1)$ & $5502(1)$ & $26(1)$ & $2610(1)$ & $390(1)$ & $5483(1)$ & $15(1)$ \\
\hline $\operatorname{Br}(1)$ & $1578(2)$ & $2301(1)$ & $7268(1)$ & $52(1)$ & $1245(1)$ & $2277(1)$ & $7082(1)$ & $19(1)$ \\
\hline $\mathrm{Br}(2)$ & $4714(2)$ & $1560(1)$ & $4862(1)$ & $40(1)$ & $4479(1)$ & $1537(1)$ & $4701(1)$ & $21(1)$ \\
\hline $\operatorname{Br}(3)$ & $1038(2)$ & $-1142(1)$ & $6307(1)$ & $39(1)$ & $1065(1)$ & $-1165(1)$ & $6349(1)$ & $19(1)$ \\
\hline $\mathrm{N}$ & $3339(11)$ & $5587(9)$ & $6997(7)$ & $37(3)$ & $3305(9)$ & $5634(6)$ & $7257(5)$ & $15(1)$ \\
\hline$C(1)$ & $1964(20)$ & $5564(28)$ & $7586(11)$ & $132(13)$ & $2742(13)$ & $5776(9)$ & $8187(7)$ & $26(2)$ \\
\hline$C(2)$ & $4161(29)$ & $6590(14)$ & $7152(13)$ & $90(8)$ & $4321(12)$ & $6527(8)$ & $7056(8)$ & $26(2)$ \\
\hline$C(3)$ & $4475(22)$ & $4749(14)$ & $7379(18)$ & $91(8)$ & $4204(12)$ & $4630(8)$ & $7267(7)$ & $24(2)$ \\
\hline$C(4)$ & & & & & $1769(10)$ & $5586(8)$ & $6574(6)$ & $18(2)$ \\
\hline$C(5)$ & $2809(13)$ & $5409(9)$ & $5921(8)$ & $28(2)$ & $2094(11)$ & $5407(7)$ & $5591(6)$ & $18(2)$ \\
\hline$C(6)$ & $2419(20)$ & $6241(12)$ & $5329(11)$ & $56(4)$ & $2240(11)$ & $6258(8)$ & $5011(7)$ & $19(2)$ \\
\hline$C(7)$ & $1944(23)$ & $6066(16)$ & $4348(12)$ & $80(7)$ & $2295(14)$ & $6075(8)$ & $4106(7)$ & $26(2)$ \\
\hline$C(8)$ & $1802(18)$ & $5083(14)$ & $3965(10)$ & $55(4)$ & $2276(11)$ & $5066(8)$ & $3757(7)$ & $21(2)$ \\
\hline$C(9)$ & $2170(27)$ & $4279(14)$ & $4582(11)$ & $83(7)$ & $2186(12)$ & $4203(8)$ & $4336(7)$ & $22(2)$ \\
\hline$C(10)$ & $2684(27)$ & $4437(13)$ & $5558(11)$ & $74(6)$ & $2072(11)$ & $4375(7)$ & $5261(6)$ & $18(2)$ \\
\hline
\end{tabular}

${ }^{a} U($ eq $)$ is defined as one third of the trace of the orthogonalized $U_{i j}$ tensor. 
Table 3. Atomic coordinates $\left(\times 10^{4}\right)$ and equivalent isotropic displacement parameters (in $\AA^{2} \times 10^{3}$ ) for 3.

\begin{tabular}{lrlll}
\hline Atom & \multicolumn{1}{c}{$x$} & $y$ & $z$ & $U(\mathrm{eq})^{a}$ \\
\hline $\mathrm{Se}(1)$ & 0 & 5000 & 5000 & $11(1)$ \\
$\mathrm{Se}(2)$ & $-1587(2)$ & $6651(1)$ & $1273(1)$ & $19(1)$ \\
$\mathrm{Se}(3)$ & $590(2)$ & $5696(1)$ & $1907(1)$ & $19(1)$ \\
$\mathrm{Br}(1)$ & $-1000(2)$ & $5384(1)$ & $3415(1)$ & $16(1)$ \\
$\mathrm{Br}(2)$ & $2903(2)$ & $5205(1)$ & $4925(1)$ & $18(1)$ \\
$\mathrm{Br}(3)$ & $-107(2)$ & $6975(1)$ & $5303(1)$ & $18(1)$ \\
$\mathrm{Br}(4)$ & $-3529(2)$ & $5352(1)$ & $834(1)$ & $28(1)$ \\
$\mathrm{Br}(5)$ & $2013(2)$ & $5521(1)$ & $856(1)$ & $27(1)$ \\
$\mathrm{N}$ & $253(12)$ & $2402(8)$ & $1762(7)$ & $14(2)$ \\
$\mathrm{C}(1)$ & $-873(18)$ & $2775(12)$ & $2261(10)$ & $27(3)$ \\
$\mathrm{C}(2)$ & $-469(17)$ & $2685(14)$ & $852(9)$ & $29(3)$ \\
$\mathrm{C}(3)$ & $331(16)$ & $1236(10)$ & $1845(9)$ & $20(3)$ \\
$\mathrm{C}(4)$ & $1868(17)$ & $2865(10)$ & $2061(8)$ & $18(3)$ \\
$\mathrm{C}(5)$ & $2359(15)$ & $3318(10)$ & $2852(8)$ & $17(3)$ \\
$\mathrm{C}(6)$ & $3918(15)$ & $3682(10)$ & $3119(8)$ & $16(2)$ \\
$\mathrm{C}(7)$ & $4937(18)$ & $3631(11)$ & $2593(9)$ & $24(3)$ \\
$\mathrm{C}(8)$ & $4436(16)$ & $3168(11)$ & $1799(9)$ & $20(3)$ \\
$\mathrm{C}(9)$ & $2924(15)$ & $2776(10)$ & $1533(8)$ & $15(2)$ \\
\hline
\end{tabular}

${ }^{a} U(\mathrm{eq})$ is defined as one third of the trace of the orthogonalized $U_{i j}$ tensor.

During the synthetic work it was observed that if more than one compound crystallized from the same solution, there was usually a break between the crystallization of the different compounds.

The anions of the present three structures all contain the $\mathrm{Se}_{2} \mathrm{Br}_{2}$ unit, which is known from the structures of $\alpha$ - and $\beta-\mathrm{Se}_{2} \mathrm{Br}_{2}$. ${ }^{1}$ The two $\mathrm{Se}_{4} \mathrm{Br}_{6}{ }^{2-}$ ions resemble the $\beta-\mathrm{Se}_{2} \mathrm{Br}_{2}$ molecule. Views of these three structures are shown in Fig. 1, and a view of the $\mathrm{SeBr}_{6}\left(\mathrm{Se}_{2} \mathrm{Br}_{2}\right)_{2}{ }^{2-}$ anion is shown in Fig. 2. Bond lengths and angles of the anions are listed in Tables 4 and 5, and selected dimensions, including those of $\alpha$ - and $\beta-\mathrm{Se}_{2} \mathrm{Br}_{2}$, are listed in Table 6.

The $\mathrm{Se}_{4} \mathrm{Br}_{6}{ }^{2-}$ ion is the first isolated complex of univalent selenium. In the crystal structure two $\mathrm{Se}_{2} \mathrm{Br}_{2}$ units are bonded together by two bromine atom bridges between selenium atoms, resulting in a chair-shaped, sixmembered, centrosymmetric ring of four selenium and two bromine atoms. The Se-Se bonds are a little, but significantly, longer in the present structures than in $\alpha$ and $\beta-\mathrm{Se}_{2} \mathrm{Br}_{2}$. The selenium atoms of the present compounds are acting as central atoms in asymmetric, nearly linear $3 c-4 e$ systems. The bond lengths of the individ-
Table 4. Bond lengths (in $\AA$ ), bond angles and torsion angles (in ${ }^{\circ}$ ) of the anions in $\mathbf{1}$ and $\mathbf{2}$.

\begin{tabular}{|c|c|c|}
\hline Compound & 1 & 2 \\
\hline $\begin{array}{l}\operatorname{Se}(1)-\operatorname{Se}(2) \\
\operatorname{Se}(1)-\operatorname{Br}(1) \\
\operatorname{Se}(1)-\operatorname{Br}(3 a) \\
\operatorname{Se}(2)-\operatorname{Br}(2) \\
\operatorname{Se}(2)-\operatorname{Br}(3) \\
\operatorname{Se}(2) \cdots \operatorname{Br}(2 b) \\
\operatorname{Se}(2) \cdots \operatorname{B}(3 a) \\
\operatorname{Se}(2) \cdots \operatorname{Se}(1 a)\end{array}$ & $\begin{array}{l}2.282(2) \\
2.419(2) \\
3.025(2) \\
2.572(2) \\
2.681(2) \\
3.460(2) \\
3.951(2) \\
4.111(2)\end{array}$ & $\begin{array}{l}2.2787(12) \\
2.4238(13) \\
3.041(2) \\
2.5250(14) \\
2.7632(13) \\
3.4934(14) \\
3.979(2) \\
3.8824(14)\end{array}$ \\
\hline $\begin{array}{l}\operatorname{Se}(2)-\operatorname{Se}(1)-\operatorname{Br}(1) \\
\operatorname{Se}(2)-\operatorname{Se}(1)-\operatorname{Br}(3 a) \\
\operatorname{Br}(1)-\operatorname{Se}(1)-\operatorname{Br}(3 a) \\
\operatorname{Se}(1)-\operatorname{Se}(2)-\operatorname{Br}(2) \\
\operatorname{Se}(1)-\operatorname{Se}(2)-\operatorname{Br}(3) \\
\operatorname{Br}(2)-\operatorname{Se}(2)-\operatorname{Br}(3) \\
\operatorname{Se}(2)-\operatorname{Br}(3)-\operatorname{Se}(1 \mathrm{a}) \\
\operatorname{Se}(1)-\operatorname{Se}(2) \cdots \operatorname{Br}(2 b) \\
\operatorname{Se}(1)-\operatorname{Se}(2) \cdots \operatorname{Br}(3 b) \\
\operatorname{Se}(1)-\operatorname{Se}(2) \cdots \operatorname{Se}(1 a)\end{array}$ & $\begin{array}{r}100.92(7) \\
95.20(6) \\
163.56(7) \\
97.14(6) \\
95.56(6) \\
166.18(6) \\
91.98(5) \\
176.16(6) \\
49.69(5) \\
89.80(6)\end{array}$ & $\begin{array}{r}101.76(5) \\
95.79(4) \\
162.31(5) \\
97.72(5) \\
94.00(4) \\
168.25(5) \\
83.82(4) \\
177.02(4) \\
49.48(3) \\
88.32(4)\end{array}$ \\
\hline $\begin{array}{l}\operatorname{Br}(1)-\operatorname{Se}(1)-\operatorname{Se}(2)-\operatorname{Br}(2) \\
\operatorname{Br}(1)-\operatorname{Se}(1)-\operatorname{Se}(2)-\operatorname{Br}(3) \\
\operatorname{Br}(2)-\operatorname{Se}(2)-\operatorname{Se}(1)-\operatorname{Br}(3 a) \\
\operatorname{Br}(3 a)-\operatorname{Se}(1)-\operatorname{Se}(2)-\operatorname{Br}(3) \\
\operatorname{Se}(1)-\operatorname{Se}(2)-\operatorname{Br}(3)-\operatorname{Se}(1 a) \\
\operatorname{Se}(2)-\operatorname{Br}(3)-\operatorname{Se}(1 a)-\operatorname{Se}(2 a)\end{array}$ & $\begin{array}{r}-85.33(7) \\
89.20(7) \\
97.97(6) \\
-87.50(5) \\
84.58(6) \\
-84.24(6)\end{array}$ & $\begin{array}{r}-97.30(5) \\
81.96(5) \\
84.93(4) \\
-95.81(4) \\
84.60(4) \\
-86.58(49)\end{array}$ \\
\hline
\end{tabular}

Symmetry transformations: (a) $-x,-y, 1-z$; (b) $1-x$, $-y, 1-z$

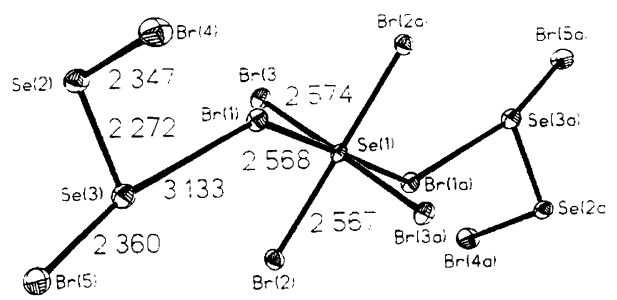

Fig. 2. View of the $\mathrm{SeBr}_{6}\left(\mathrm{Se}_{2} \mathrm{Br}_{2}\right)_{2}{ }^{2-}$ ion as found in the phenyltrimethylammonium salt.

ual $3 c-4 e$ systems are $2.419(2) / 3.025(2) \AA$ and $2.572(2) / 2.681(2) \AA$ in 1 and $2.424(1) / 3.041(2) \AA$ and $2.525(1) / 2.763(1) \AA$ in 2 . The longer bonds are to the bridging bromine atoms in the six-membered ring. In $\alpha$ - and $\beta-\mathrm{Se}_{2} \mathrm{Br}_{2}$ the $\mathrm{Se}-\mathrm{Br}$ bonds are in the range 2.357(2)-2.369(1) $\AA$. ${ }^{1}$ The corresponding bonds
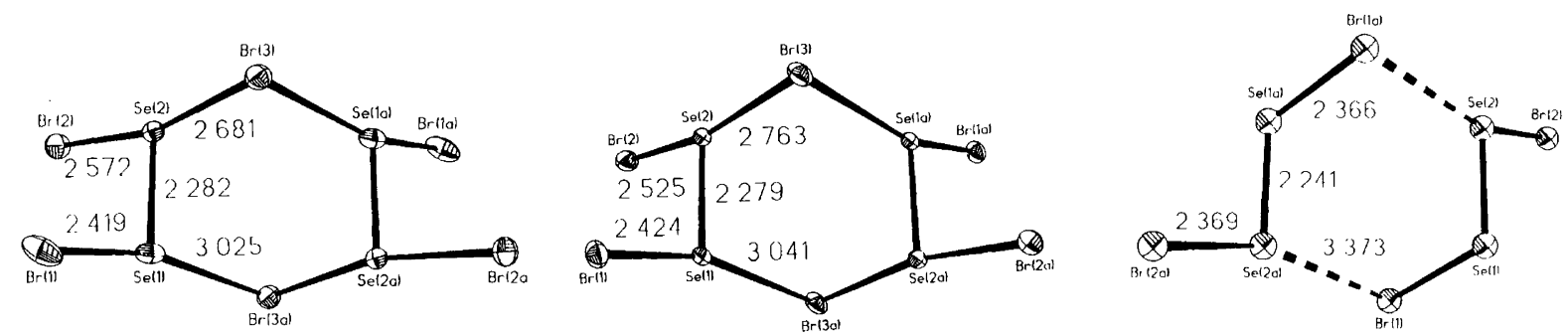

Fig. 1. View of the $\mathrm{Se}_{4} \mathrm{Br}_{6}{ }^{2-}$ ion as found in the phenyltrimethylammonium salt (left) and the benzyltrimethylammonium salt (middle), and the $\mathrm{Se}_{2} \mathrm{Br}_{2}$ molecule as found in the $\beta$ modification' (right). 
Table 5. Bond lengths (in $\AA$ ), bond angles and torsion angles (in $\%$ of the anion in 3 .

\begin{tabular}{llll}
\hline $\operatorname{Se}(1)-\operatorname{Br}(1)$ & $2.5675(13)$ & $\operatorname{Se}(2)-\operatorname{Br}(4)$ & $2.347(2)$ \\
$\operatorname{Se}(1)-\operatorname{Br}(2)$ & $2.5673(14)$ & $\operatorname{Se}(3)-\operatorname{Br}(5)$ & $2.360(2)$ \\
$\operatorname{Se}(1)-\operatorname{Br}(3)$ & $2.5742(14)$ & $\operatorname{Se}(3)-\operatorname{Br}(1)$ & $3.133(2)$ \\
$\operatorname{Se}(2)-\operatorname{Se}(3)$ & $2.272(2)$ & $\operatorname{Se}(2) \cdots \operatorname{Br}(3 b)$ & $3.541(2)$ \\
$\operatorname{Br}(1)-\operatorname{Se}(1)-\operatorname{Br}(2)$ & $91.37(5)$ & $\operatorname{Se}(3)-\operatorname{Se}(2)-\operatorname{Br}(4)$ & $102.40(8)$ \\
$\operatorname{Br}(1)-\operatorname{Se}(1)-\operatorname{Br}(2 a)$ & $88.63(5)$ & $\operatorname{Se}(2)-\operatorname{Se}(3)-\operatorname{Br}(5)$ & $104.22(7)$ \\
$\operatorname{Br}(1)-\operatorname{Se}(1)-\operatorname{Br}(3)$ & $89.29(4)$ & $\operatorname{Se}(2)-\operatorname{Se}(3)-\operatorname{Br}(1)$ & $167.03(6)$ \\
$\operatorname{Br}(1)-\operatorname{Se}(1)-\operatorname{Br}(3 a)$ & $90.71(4)$ & $\operatorname{Se}(1)-\operatorname{Br}(1)-\operatorname{Se}(3)$ & $135.46(6)$ \\
$\operatorname{Br}(2)-\operatorname{Se}(1)-\operatorname{Br}(3)$ & $89.53(4)$ & $\operatorname{Se}(3)-\operatorname{Se}(2) \cdots \operatorname{Br}(3 b)$ \\
$\operatorname{Br}(2)-\operatorname{Se}(1)-\operatorname{Br}(3 a)$ & $90.47(4)$ & & \\
$\operatorname{Br}(4)-\operatorname{Se}(2)-\operatorname{Se}(3)-\operatorname{Br}(5)$ & $97.49(8)$ & & \\
\hline
\end{tabular}

Symmetry transformations: (a) $-x, 1-y, 1-z$; (b) $x-1 / 2,1 \frac{1}{2}-y, z-1 / 2$.

Table 6. Distances (in $\AA$ ) and angles (in ") of $\mathrm{Se}_{2} \mathrm{Br}_{2}$ molecules and $\mathrm{Se}_{2} \mathrm{Br}_{2}$ units of other compounds.

\begin{tabular}{|c|c|c|c|c|c|}
\hline & $\mathrm{Se}_{4} \mathrm{Br}_{6}^{2-}$ & $\begin{array}{l}\mathrm{Se}_{4} \mathrm{Br}_{6}{ }^{2-} \\
2\end{array}$ & $\mathrm{Se}_{5} \mathrm{Br}_{10}{ }^{2-}$ & $\begin{array}{l}\mathrm{Se}_{2} \mathrm{Br}_{2} \\
4\end{array}$ & $\begin{array}{l}\beta-\mathrm{Se}_{2} \mathrm{Br}_{2} \\
\mathbf{5}\end{array}$ \\
\hline $\begin{array}{l}\mathrm{Se}-\mathrm{Se} \\
\mathrm{Br}-\mathrm{Se}-\mathrm{Br}-\mathrm{Se}^{a}\end{array}$ & $\begin{array}{l}2.282(2) \\
85.33(7)\end{array}$ & $\begin{array}{c}2.279(1) \\
97.31(5)\end{array}$ & $\begin{array}{c}2.272(2) \\
97.49(8)\end{array}$ & $\begin{array}{l}2.258(2) \\
85.0(1)\end{array}$ & $\begin{array}{l}2.241(1) \\
86.41(8)\end{array}$ \\
\hline $\begin{array}{l}\mathrm{Se}-\mathrm{Br} \\
\mathrm{Se}-\mathrm{Se}-\mathrm{Br} \\
\mathrm{Se} \cdot \cdots \mathrm{Br} \\
\mathrm{Br}-\mathrm{Se} \cdots \mathrm{Br}\end{array}$ & $\begin{array}{c}2.419(2) \\
100.92(7) \\
3.025(2) \\
163.56(7)\end{array}$ & $\begin{array}{c}2.424(1) \\
101.76(5) \\
3.041(2) \\
162.31(5)\end{array}$ & $\begin{array}{c}2.347(2) \\
102.40(8)\end{array}$ & $\begin{array}{c}2.357(2) \\
107.23(8)\end{array}$ & $\begin{array}{c}2.366(1) \\
103.86(5)\end{array}$ \\
\hline $\begin{array}{l}\mathrm{Se}-\mathrm{Br} \\
\mathrm{Se}-\mathrm{Se}-\mathrm{Br} \\
\mathrm{Se} \cdots \mathrm{Br} \\
\mathrm{Br}-\mathrm{Se} \cdot \cdots \mathrm{Br} \\
\text { Ref. }\end{array}$ & $\begin{array}{c}2.572(2) \\
97.14(6) \\
2.681(2) \\
166.18(6) \\
\text { This work }\end{array}$ & $\begin{array}{c}2.525(1) \\
97.72(5) \\
2.763(1) \\
168.26(5) \\
\text { This work }\end{array}$ & $\begin{array}{c}2.360(2) \\
104.22(7) \\
3.133(2) \\
166.24(7) \\
\text { This work }\end{array}$ & 1 & $\begin{array}{c}2.369(1) \\
104.51(5) \\
3.373(1) \\
162.3 \\
1\end{array}$ \\
\hline
\end{tabular}

${ }^{a}$ Torsion angle.

in the present structures are considerably longer, $2.419(2)-2.572(2) \AA$, a pronounced effect of the $3 c-4 e$ systems. The $\mathrm{Se}-\mathrm{Se}-\mathrm{Br}$ (terminal) angles are in the range 97.14(6)-101.76(5) $)^{\circ}$ In accordance with observations in divalent and tetravalent selenium complexes the selenium atom which is involved in the most symmetrical $3 c-4 e$ system has the smallest angle, and when the two bonds are equal the angle is expected to be $90^{\circ}$. The largest observed differences between the two crystal structures are in the $\mathrm{Se}-\mathrm{Br}-\mathrm{Se}$ angles and some of the torsion angles. These differences might be a result of small differences in the packing caused by the different size of the cations. The $\operatorname{Se}(2)-\operatorname{Br}(3)$ bond in 2 is longer than in 1, whereas the trans-positioned $\operatorname{Se}(2)-\operatorname{Br}(2)$ bond is shorter. A variation of this type is usual in $3 c-4 e$ bonds. At $\operatorname{Se}(1)$ there are only minor differences in angles and bond lengths between the two structures. In the direction of the $\mathrm{Se}-\mathrm{Se}$ bond, $\mathrm{Se}(2)$ has a weak bond to $\operatorname{Br}(2)$ of an adjacent $\mathrm{Se}_{4} \mathrm{Br}_{6}{ }^{2-}$ unit. The $\mathrm{Se} \cdot \mathrm{Br}$ distance is $3.460(2) \AA$ in 1 and 3.493(2) $\AA$ in 2, and the Se-Se $\cdots \mathrm{Br}$ angle is $176.16(6)^{\circ}$ in 1 and $177.02(4)^{\circ}$ in 2 . Since $\operatorname{Se}(2)$ already is bonded to three atoms it can not accept more electrons and therefore probably acts as donor in this bond. Complex bonded divalent selenium has earlier been observed in this role..$^{6,7,21,22}$

A comparison of $\mathrm{Se}-\mathrm{Br}$ bond lengths in $\mathrm{Se}^{\mathrm{I}}, \mathrm{Se}^{\mathrm{II}}$ and $\mathrm{Se}^{\mathrm{IV}}$ complexes is not easy, since the asymmetric bonds show great variation, and bonds related through a centre of symmetry are not available for $\mathrm{Se}^{\mathrm{I}}$. For centrosymmetric tetravalent octahedral complexes the weighted mean value for 13 individual $\mathrm{Se}-\mathrm{Br}$ bonds is $2.570(3) \AA,{ }^{11}$ and when the asymmetry of a $\mathrm{Br}-\mathrm{Se}-\mathrm{Br}$ system is moderate, e.g. $2.483(3)$ and $2.670(3) \AA{ }^{23}$ the average is nearly the same, $2.577 \AA$. For centrosymmetric or near centrosymmetric square-planar divalent selenium complexes, the average $\mathrm{Se}-\mathrm{Br}$ bond is $2.595 \AA,^{3,4}$ and also here the average of a moderate asymmetric system, e.g. $2.485(1)$ and $2.710(1) \AA{ }^{3}$ is nearly the same, $2.598 \AA$. The $\operatorname{Br}(2)-\operatorname{Se}(2)-\operatorname{Br}(3)$ system in 1 has $\mathrm{Se}-\mathrm{Br}$ bonds 2.572(2) and 2.681(2) $\AA$. This is an even more moderate asymmetry than in the former cases, and the bond of a symmetric system is expected to be only slightly less than the average value, $2.627 \AA$. One might conclude that in selenium complexes with bromine as ligands the length of the $\mathrm{Se}-\mathrm{Br}$ bond decreases with increasing oxidation state of selenium, in accordance with the change in the coulomb attraction.

The complex ion $\mathrm{SeBr}_{6}\left(\mathrm{Se}_{2} \mathrm{Br}_{2}\right)_{2}{ }^{2-}$ is one of the most unique selenium complexes, built up of a nearly regular octahedral $\mathrm{SeBr}_{6}{ }^{2-}$ ion and using two of the bromine ligands as bridges to two $\mathrm{Se}_{2} \mathrm{Br}_{2}$ molecules. In the crystals, the tetravalent selenium lies in a centre of symmetry. The three crystallographically independent $\mathrm{Se}-\mathrm{Br}$ bonds are equal within experimental error, with a 
mean value of $2.570(4) \AA$, the same as that found earlier for $\mathrm{SeBr}_{6}{ }^{2-}$ ions. ${ }^{11}$ The contact between $\mathrm{Br}(1)$ and $\mathrm{Se}(3)$ is probably a bond of the donor-acceptor adduct type, with $\mathrm{Br}(1)$ as donor and the $\mathrm{Se}_{2} \mathrm{Br}_{2}$ molecule as acceptor. Donor-acceptor adducts with bromine coordinated to $\mathrm{Se}^{\mathrm{IV}}$ as donor have been observed earlier, but then with a bromine molecule as acceptor. In $\left[\mathrm{C}_{6} \mathrm{H}_{5}\left(\mathrm{CH}_{3}\right)_{3} \mathrm{~N}\right]_{2 n}\left[\mathrm{Se}_{2} \mathrm{Br}_{10} \cdot \mathrm{Br}_{2}\right]_{n}{ }^{11}$ the $\mathrm{Se}-\mathrm{Br}-\mathrm{Br}_{2}$ angle is $114.23(8)^{\circ}$, with $\mathrm{Se}-\mathrm{Br}$ bond length of 2.573(2) $\AA$ and a $\mathrm{Br}-\mathrm{Br}_{2}$ bond length of 3.097(2) $\AA$. In $\left[\left(\mathrm{CH}_{3}\right)_{3} \mathrm{HN}\right]_{2 \mathrm{n}}\left[\mathrm{SeBr}_{6} \cdot \mathrm{Br}_{2}\right]_{n}{ }^{10}$ the angle is $163.5(1)^{\circ}$ and the bond lengths are 2.678(3) and 2.987(3) $\AA$. In the first case the acceptor, $\mathrm{Br}_{2}$, does not have an apparent influence on the length of the complex $\mathrm{Se}-\mathrm{Br}$ bond. In the second case the $\mathrm{Se}-\mathrm{Br}-\mathrm{Br}_{2}$ string is much more linear and the influence on the complex bond is obvious; the $\mathrm{Se}-\mathrm{Br}$ bond is lengthened by $0.1 \AA$. In the present crystal structure the angle is $135.46(6)^{\circ}$ and no influence on the complex bond is observed. It seems that the acceptor has to be co-linear with $\mathrm{Br}-\mathrm{Se}-\mathrm{Br}$ to have an influence on the $\mathrm{Se}-\mathrm{Br}$ bond, and the influence is hardly detected when $\mathrm{Se}$ is situated in a centre of symmetry.

The $\mathrm{Se}_{2} \mathrm{Br}_{2}$ parts of the structure show a great resemblance to the structures of $\alpha$ - and $\beta-\mathrm{Se}_{2} \mathrm{Br}_{2}$, and $\mathrm{Se}_{4} \mathrm{Br}_{6}{ }^{2-}$. However, $\beta-\mathrm{Se}_{2} \mathrm{Br}_{2}$ and $\mathrm{Se}_{4} \mathrm{Br}_{6}{ }^{2-}$ both form six-membered rings, whereas the $\mathrm{Se}_{2} \mathrm{Br}_{2}$ parts of this ion have more open structures. It is mentioned above that the $\mathrm{Se}_{2} \mathrm{Br}_{2}$ parts are acceptors in a donor-acceptor adduct. In the two other adducts referred to, the two bromine atoms of the acceptor and the bromine donor are nearly linear. In the present compound the corresponding angle, $\operatorname{Br}(5)-\mathrm{Se}(3)-\mathrm{Br}(1)$, is $166.24(7)^{\circ}$. As usual, the bond within the acceptor is only a little affected by the contact, and the bond between the donor and the acceptor is long, 3.133(2) $\AA$. Since $\operatorname{Br}(4)$ has no contact with any other atom than $\operatorname{Se}(2)$ and there is no contact to $\operatorname{Se}(2)$ trans to the $\mathrm{Se}(2)-\mathrm{Br}(4)$ bond, this bond, 2.347(2) $\AA$, may be regarded as covalent, indicating a covalent radius of about $1.21 \AA$ for $\mathrm{Se}^{\mathrm{I}}$. The $\mathrm{Se}-\mathrm{Se}$ bond lengths of the monovalent selenium compounds listed in Table 6 are shorter than the covalent Se-Se bond, $2.32 \AA,{ }^{24}$ or $2.42 \AA$ if the radius from above is used, and probably have some double bond character.

The dimensions of the cations of the present structures do not deviate from the usual values.
Acknowledgements. This work was supported by The Research Council of Norway.

\section{References}

1. Kniep, R., Korte, L. and Mootz, D. Z. Naturforsch., Teil B 38 (1983) 1 .

2. Born, P., Kniep, R and Mootz, D. Z. Anorg. Allg. Chem. 451 (1979) 12

3. Krebs, B., Schäffer, A. and Pohl, S. Z. Naturforsch., Teil B 39 (1984) 1633.

4. Hauge, S., Janickis, V. and Marøy, K. Acta Chem. Scand. 52 (1998) $441\left(\mathrm{SeBr}_{4}{ }^{2-}\right)$.

5. Hauge, S., Janickis, V. and Marøy, K. Acta Chem. Scand. 52 (1998) $435\left(\mathrm{Se}_{2} \mathrm{Br}_{6}{ }^{2-}\right)$.

6. Hauge, S., Marøy, K. and Ødegárd, T. Acta Chem. Scand., Ser. A 42 (1988) 51.

7. Krebs, B., Ahlers, F-P. and Lührs, E. Z. Anorg. Allg. Chem. 597 (1991) 115.

8. Beckmann, I. Ph.D. Thesis. University of Münster, Germany 1994.

9. Beckmann, I., Bonmann, S., Hasche, S. and Krebs, B. The VIIth International Conference on the Chemistry of Selenium and Tellurium (1997) PC-14.

10. Krebs, B. and Ahlers, F-P. Adv. Inorg. Chem. 35 (1990) 235.

11. Hauge, S. and Marøy, K. Acta Chem. Scand. 50 (1996) 399.

12. Ahlers, F.-P. Ph.D. Thesis. University of Münster, Germany 1991.

13. Hasche, S., Reich, O., Beckmann, I. and Krebs, B. Z. Anorg. Allg. Chem. 623 (1997) 724.

14. Ahlers, F.-P., Lührs, E. and Krebs, B. Z. Anorg. Allg. Chem. 594 (1991) 7.

15. Milne, J. Polyhedron 4 (1985) 65.

16. Lamourex, M. and Milne, J. Polyhedron 9 (1990) 589.

17. Harms, K. Program for Correction of Enraf-Nonius CAD4 Data. University of Marburg, Germany 1996.

18. Sheldrick, G. M. SHELXS86. Program for the Solution of Crystal Structures. University of Göttingen, Germany 1986.

19. Sheldrick, G. M. SHELXL93. Program for the Refinement of Crystal Structures. University of Göttingen, Germany 1993.

20. International Tables for Crystallography, Vol. C. Kluwer Academic Press, Dordrecht 1992.

21. Hauge, S. Acta Chem. Scand., Ser. A 29 (1975) 771.

22. Hauge, S. Acta Chem. Scand., Ser. A 29 (1975) 843.

23. Bonmann, S., Eideschink, I. and Krebs, B. Z. Kristallogr., Suppl Nr. 5 (1992) 29.

24. Saethre, L. J. and Gropen, O. Can. J. Chem. 70 (1992) 348.

Received January 30, 1998. 